\title{
Insurance as a Form of Tourism Protection
}

\author{
Desak Gde Dwi Arini, Diah Gayatri Sudibya, I Wayan Werasmana Sancaya \\ Faculty of Law \\ Universitas Warmadewa \\ Denpasar-Bali, Indonesia \\ desakarini1966@gmail.com
}

\begin{abstract}
This research belongs to a normative and empirical legal research to identify the construction of insurance law against the risks confronted in the field of tourism. Secondary data obtained from primary legal materials, encompassing legislation, such as the Civil Code, the Book of Commercial Law, and Law Number 10 of 2009 on Tourism and Law Number 40 of 2014. In addition, primary data are obtained through observation and interviews, from the field involving relevant institutions and companies with insurance. The results of the research show that generally the insurance in the tourism sector is performed through the initiative of tourism service providers (Hotel Entrepreneur, Tour and Travel Bureau, and the manager of the tourism object) due to the sense of responsibility. Thus, insurance in tourism is a responsibility and incidental insurance occurred in the area of tourist attraction, which is classifiable into insurance of the third parties' interest. Insured interests include life, personal accident, health, and the loss of tourism goods due to fire and responsibility. Similarly, determination of indemnity to be paid by the insurer is not based on actual losses but is determined at the beginning of the insurance agreement.
\end{abstract}

Keywords-insurance; tourism; protection; tourist; Bali Province

\section{INTRODUCTION}

The development is a business or a series of growth efforts and planning changes made consciously by a nation, state and government toward modernity in the effort of nation building [1].

One of the main sectors in the development of the nation and government of the Republic of Indonesia in the decade of the $1980 \mathrm{~s}$ is the development of tourism sector, the constellation and the world of tourism and its development and its possibilities in the future. The tourism industry in Indonesia can now be said to appear in a real presence. Law Number 10 in 2009 on Tourism, outlines the Indonesian economy requires an increase in tourism to cultivate economic potentials into real economic forces [2].

In the case of visiting recreational places for example, there is a tendency to make sunlight and sea as a tourist attraction. Thus, building tourism becomes something easy to build the economy. By simply exploiting the beauty of nature, they (countries) try to overcome difficulties in balance of payment deficit.

A balanced growth for the economy can occur as a result of the development of a well developed tourism industry. Not only hotel companies can provide rooms to stay, food and beverages (bar and restaurant), travel plans (tour operators), travel agents, handicraft industries are required, but also economic infrastructure, such as highways, bridges, port terminals, airfields. In addition it also needs power generation infrastructure, facilities by sports and recreation, post and telecommunications, banks, money changer, insurance companies, advertising companies and many other sectors of the economy.

Tourism as a service industry classified as a third industry, [3] plays an important role in establishing policies on employment. The reason is the increasingly urgent demand for permanent employment in relation to ever-increasing tourism in the future.

The role of tourism in the development of the outline is essentially three facets, namely the economic (tax source), the social (employment), and cultural aspects (introducing culture to tourists). These three aspects not only apply to foreign tourists, but also to the increasingly increasing domestic tourist role [4]

During the tourism activities, the tourists both in a visit to the tourist attraction or in lodging (hotel), or on other activities included in the scope of tourism, tourists are faced with an uncertain circumstance commonly referred to as risk [5]. The possibility that humans will be at risk, both to their souls and possessions has been a problem for mankind ever since. To overcome the risks in reality there are several ways or efforts made by humans.

One attempt to reduce the risk is to transfer the risk to the other party. Similarly, the risk will be experienced by tourists. This is intended to provide protection to the sense of security to tourists, namely by entering into an agreement of this kind is called an insurance agreement [5].

The emergence of a policy to provide protection to tourists, both foreign tourists and tourists domestic in the form of insurance, due to the increasing number of dynamics of human life, allowing more opportunities for the occurrence of events that cause losses and so do tourists to travel during the tour. Based on the background of the above problems, it can be reviewed some of the following issues: how the procedure of the implementation of tourism insurance agreement and how the form of legal protection for tourists in tourism insurance agreement. 


\section{METHOD}

Type of research the employed is normative legal and empirical law researches. Normative legal research is used bringing out analysis on the written regulations or legal materials. Empirical legal research is a field primary data-based study. There are two types of data exploited in this study, comprising primary and secondary data. Secondary data obtained of primary legal materials, encompassing legislation, such as the Civil Code, the Book of Commercial Law, and Law Number 10 of 2009 on Tourism and Law Number 40 of 2014. In addition, primary data are obtained through observation and interviews, from the field involving relevant institutions and companies with insurance. Secondary data are in the form of legal material obtained from the literature or opinions of scholars related to the recent issues discussed in the study.

\section{RESULT AND DISCUSSION}

\section{A. Procedure of Insurance Tourism Agreement}

According to Article 1338 paragraph (1) of the Civil Code known as article contains the principle of freedom of contract because underlying insurance agreement between the insurer and the customer is more emphasized on the agreement between the parties, namely the agreement of the insurer as the insurer and the customer as the insured. In practice, in the insurance agreement there are two parties who entered into an agreement called the subject of insurance i.e. the insurer, whose term is called verzekeraar and the insured who entered into agreements with the term verzekerde. Insurers are parties who bear the risk, while the insured is the party who divert the risk of wealth or soul to the insurer. The insurer is the insurer and the insured is a supporter of rights and obligations. Insurer shall bear the risk transferred to him and shall be entitled to a premium payment, while the insured shall pay the premium and shall be entitled to a replacement in the event of loss on his property insured. The insurer must be a legal entity, may be a Limited Liability Company (PT), an Incorporated Liability Company (Persero) or a cooperative, while the insured may be an individual, a partnership, or a legal entity, whether as a company or not a company. Insured status as the owner or party concerned on the property insured.

The insurance relationship between the insurer and the insured is the legally bound arising out of free agreement or agreement. These attachments are voluntary willingness of the insurer and the insured to fulfill the obligations of their respective rights to each other (mutually). This means that since the insurance agreement reached, the insured is bound and must pay insurance premiums to the insurer, and since then also the insurer received the transfer of risk. In the event of an event causing losses on an insurance object, the insurer shall pay compensation in accordance with the provisions of the insurance policy. Conversely if there is no event, the premium already paid by the insured remains the property of the insurer.

The insurance agreement is part of the agreement generally known by the term of engagement as set forth in Book III of Civil Code, furthermore from insurance agreement known as insurance contract term, where basically between insurance agreement with insurance contract have the same meaning and purpose, that is: as an agreement made by the insurer or the insurer with the customer or the insured, which has the objective to regulate the rights and obligations of both parties on a reciprocal basis, bringing the consequences/legal consequences therein [6].

An agreement in an insurance agreement is an essential element. This is the first element for the validity of a treaty under Article 1320 of the Civil Code. In case of coercion (dwang), dwaling, or fraud (bedrog), the agreement may be canceled. This is due to a defect in the will of the agreed element of the insurance agreement. By agreement means that the parties between the insurer and the insured agree to regulate the terms of the contents of the agreement, the rights and obligations and the legal consequences of the agreement. If the agreement is violated, the offending party may demand that the other party be subject to sanctions.

The procedure of the tourism insurance agreement is said to be legitimate must meet the requirements mentioned in Article 1320 Civil Code namely the first condition there must be agreement among the parties in this case the insurer, the Tourism Office, Travel Agent and the tourist, the second condition is capable of the parties from the legal aspect must be adults and aged 21 years, the third condition is a certain thing means the object of insurance must be clear, and the four halal causa conditions.

In the tourism insurance agreement, although it has been fulfilled the provision, the article has not been sufficiently inadequate to provide protection for the insurer, so that regulated in Article 251 of the Commercial Code is about the necessity of the existence of an acquittal of all circumstances known by stunned on the insured object. Meanwhile Article 255 of the Commercial Code states that a tourism insurance agreement must be made in writing in a deed called Polis.

Thus the insurance agreement is a reciprocal agreement. In this regard, the parties, namely the insurer and the insured, each have the rights and obligations facing each other. These rights and obligations can be inferred from the provisions of the Commercial Code and the policy which is a proof of the closing of the agreement.

The right and obligation of the insured and the insurer are mutual insurance agreements. In order for the insurance agreement to be carried out properly, each party is required to perform its obligations based on good faith which is an important principle in general agreement as set forth in Article 1338, paragraph 3 of the Civil Code.

Written promise to the insured (customer) lays the obligation to meet the achievement, if he does not carry out the obligation is not due to circumstances force then the insurer is considered to break a promise. There are four forms of broken promises [7]:

- Not doing what he or she is willing to do;

- Implementing what is promised but not as promised;

- Undertaking what is promised but too late;

- Proceeding something that according to the agreement should not be done. 
In the case of the insured is no longer able to fulfill his achievement, then said the insured does not fulfill the achievement at all, whereas if the insured's achievement can still be expected fulfillment, then classified into the late meet the achievement, if the insured meets the performance is not good, he is considered late to meet the achievement, his performance can still be improved and if not, then it is considered not to meet the achievement at all.

Breach of promise brings the adverse consequences for the insured, since from that moment the insurer is obliged to compensate for the losses incurred as a result of breaking the promise. In the event that the insurer breaks a promise, the insured can sue [7]:

- Fulfillment of the Engagement

- Compliance with compensation;

- Indemnify;

- Cancellation of mutual agreement;

- Cancellation with compensation.

Replacing this loss may be a substitute for principal achievement, but may also be in addition to its core accomplishments. In the first case of indemnification occurs, because the insured does not meet the achievements at all, while the latter, because the insured late to meet the achievement.

Breach of promise does not happen immediately from the moment the insured does not fulfill his achievement, for it takes a decent grace period, for example, a week or a month. So to the agreements, where not specified in the period of its accomplishment, breaking the promise does not happen by law. Although the approval time of its achievement is determined, this does not mean that the time is already the last time limit for the insured to fulfill his performance, since often the timing is meant that the insured is not required to fulfill his performance before that time.

\section{B. Form of Legal Protection for Travelers in Tourism Insurance Agreement}

To overcome the risks in reality there are several ways or efforts made by humans. One of the efforts taken to reduce risk is to transfer the risk to the other party.

Similarly, the risk will be experienced by tourists. This is intended to provide protection/protection of the sense of security to a tourist that is by entering into an insurance agreement [5].

Based on data at the Bali Tourism Provincial Office, the insurance company that takes over the risks experienced by the tourists is the Insurance Company Loss Services Raharja and Insurance Services Company Indonesia.

In insurance in tourism, the risk of foreign and domestic tourists that can be protected is:

1) In the insurance company, the risk of a protected traveler is limited to the risk of accidents that result in tourists.
- Passing away, in the form of death benefit;

- Fixed defect, in the form of permanent disability benefit;

- Body injuries, in the form of treatment compensation.

2) In Indonesia's insurance companies, the risk of protected tourists includes: personal accident causing death, life disability, maintenance costs, and loss of property and interest of responsibility.

3) At hotel entrepreneur, the risk of protected tourists includes: individual accident (death, permanent disability, maintenance cost) and loss of tourist property.

4) Travel and Travel Bureau, the risk of protected tourists includes: loss of passport, individual accident (death, permanent disability, and maintenance cost), loss of property and return of tourist.

Thus the risks in insurance in the field of tourism can be classified as personal accident insurance which aims to guarantee accidental losses on self-insured (tourists) that cause death, permanent disability and bodily injury.

In the Personal Accident Insurance Policy mentioned:

1) What is meant by "accident" is violence, including a physical or chemical bias, directed from the outside to the body of the insured immediately causing the injury of its nature and the place may be determined by the doctor.

2) What is also regarded as an accident, that is:

a) Poisoning by inhalation of toxic gasses or fumes, except toxicity due to accidental use of drugs or other substances which may be suspected of adverse effects, or the use of drugs in the broadest sense of the word.

b) Outbreaks with substances containing pests of disease as a result of the insured by accidentally drowning in water or a liquid or solid liquid;

c) Passing away or sunset;

d) Alienation in isolation from external disasters, such as shipwrecks, emergency landing and collapse, but only as far as the consequences of being hungry, thirsty or deprived of energy;

e) Powerfully overpowered, which instantly inflicts deep wounds, whose nature and place can be determined by the physician, but only of the following consequences:

- While not able to work (c), most for 240 days, not counting the days of the week.

- Doctor care costs (c and d), without prejudice to what sub f.

f) The occurrence of lumbago or inflammation (tendo vaginitis crepitaus) but only of the following consequences:

- While not able to work (c) within the 20th day of the first day that can be calculated from the day following the day it starts but the new start running 
on the day following the day of treatment the doctor or the healer starts;

- Doctors' medical expenses (c and d) during the first 20 days, calculated from the day of treatment by the physician or the licensed physician, on $\mathrm{c}$ to a maximum of 18 times the amount of money borne for temporary inability to work, and on up to as high as one-tenth of the amount of money borne by physician (d). (Data Source: Personal Accident Insurance Policy Insurance Losses Jasa Raharja and Personal Accident Insurance Services Indonesia).

The risk of accidents assured is

- Since they depart from the inn/hotel by riding or using the vehicle up to the beginning of the activity (reception complex).

- Since leaving from the beginning of the activity and during the program activities from start to point to the finish point that has been determined.

- During the journey from the finish point until the end of the day after arriving at the inn/hotel. (Source of data: Closing Agreement on Personal Accident Insurance Between PT Sobek Bali Utama and Indonesian Insurance Company)

In close cooperation Personal Accident Insurance, mentioned:

1) Total coverage and insurance coverage

a) This personal accident insurance guarantees an accident that results in the object of coverage (all guests of domestic and foreign tourists);

- Passing away is mentioned insurance " $\mathrm{A}$ "

- A lifetime disability is called an insurance " $\mathrm{B}$ "

- The incidence of medical expense/treatment is called insurance " $D$ "

b) The sum insured/amount of detailed benefit as follows:

- Passing away (“A”): US \$ 50.000,00/person

- Fixed defect(“B”): in accordance with the terms of the parent policy with the maximum: US4 $50.000,00 /$ person

- Treatment ("D"): in accordance with the evidence of treatment/treatment issued by the authorized institution with the maximum: US\$ $5.000,00 /$ person.

\section{2) Calculation of Premium}

The amount of premium calculated at the beginning of each month directly amounted to US \$ 1,250.00/month excluding the cost of the policy and stamp duty. And it is agreed that the payment of premiums and losses shall be calculated in rupiah currency at an agreed exchange rate at the prevailing exchange rate at PT. Sobek Bali Utama.
The process of filing Claim and Compensation of insurance tourism agreement on foreign tourists and domestic tourists through the following stages:

1) Any accident occurring on the part of the guest belonging to the object of the coverage, the first party shall report immediately to the second party within seventy two hours since the incident either oral, telephone/facsimilie and hereinafter shall be confirmed by a written report with a proof - evidence and documents as follows:

- The first party's written report follows the doctor's statement (the form is provided by a second party)

- Evidence of participants in the form of:

- Proof of registration of participants/group

- News of the authorities or verbal processes in the event of serious injury or death.

- In the event of death, exerting a post mortem in the repertum and a medical death certificate (doctor) as well as the statement of the victim's heirs.

- In the case of permanent disability, it is mandatory to issue a doctor's certificate/analysis explaining the disability as a direct result of a guaranteed accident in the terms of the policy.

- In the event of accidental medical expenses incurred, the first party is required to submit a medical treatment receipt, a prescription copy and a purchase note from the doctor or hospital.

2) Medical expenses may be payable for a period of 60 (sixty) days after the event of an accident, except where required by physician to be treated 120 (one hundred and twenty) days if treatment is performed in the country of origin with the recommendation of a doctor in the country. Any transfer of the treating physician or hospital should be upon the recommendation of a physician and/or a previous hospital.

3) The first party shall provide an opportunity for a second party to conduct an on the spot check on the physical object of coverage.

\section{CONCLUSION}

The insurance agreement procedure in tourism is basically the same as the agreement in general. The procedure of tourism insurance agreement is legally obligated to fulfill 4 terms of validity of the agreement pursuant to Article 1320 Civil Code, namely: they agree to bind themselves; the presence of the ability to make the engagement; there is a promised object (certain thing); and a halal or halal cause, but the conditions set forth in Article 1320 of the Civil Code specifically for tourism insurance agreements are still unsatisfactory, because it is supplemented by the provision of Article 251 of the Criminal Code which requires the notification of all concerning the known conditions by the insured regarding the object of the insured. The form of legal protection for tourists in tourism insurance agreements in Bali Province can provide protection for foreign tourists and domestic tourists who do tourism 
activities in Bali in particular. The form of protection is protected by insurance in the field of tourism, in each company provides a diverse protection, but the risk of accidents is most often receive compensation from the insurance company that resulted in the death of death in the form of compensation, permanent disability is in the form of permanent disability benefits and body injuries in the form of treatment compensation. With a guaranteed coverage period is determined from the beginning of the tourism insurance agreement. Thus the risks protected by tourism insurance can be classified as personal accident insurance.

\section{ACKNOWLEDGEMENT}

The author would like to thank all the parties who have helped and contributed in the writing of this article, both those who contribute in the form of funding and critical ideas. Hopefully this paper can be useful theoretically and practically for the addition and development of knowledge, especially in the field of legal science.

\section{REFERENCES}

[1] Siagian, S. P. Administrasi Pembangunan, Gunung Agung, Jakarta. 2005.

[2] Undang-Undang Nomor 10 Tahun 2009 Tentang Kepariwisataan.

[3] J. J. Splillance, Ekonomi Pariwisata Sejarah dan Prospek, Kanisius, Yogyakarta. 2001.

[4] A. Hartoko, Perkembangan Pariwisata, Kesempatan Kerja dan Permasalahannya, Prisma III Nomor 2 Februari, Jakarta. 2004.

[5] S. R. Hartono, Hukum Asuransi dan Perusahaan Asuransi, Sinar Grafika, Jakarta. 2002.

[6] Tabrani and A. Geofani, Hukum Perburuhan Indonesia, Yayasan Obor Indonesia, Jakarta. 2008.

[7] Soebekti. R, Pokok-Pokok Hukum Perdata, PT. Intermasa, Jakarta. 2002. 